\title{
Characterization of cocoyam (Xanthosoma spp.) corm flour from the Nazareno cultivar
}

\author{
Diana Carolina CORONELL-TOVAR ${ }^{1}$, Rosa Nilda CHÁVEZ-JÁUREGUI ${ }^{1,2 *}$, Ángel BOSQUES-VEGA², \\ Martha Laura LÓPEZ-MORENO 3
}

\begin{abstract}
The present study assessed the physical, chemical, functional, and microbiological properties of cocoyam (Xanthosoma spp.) corm flour made from the Nazareno cultivar. The flour was initially submitted to a water-soaking process in order to reduce its high oxalate content. The soaked flour showed a high dietary fiber content (15.4\% insoluble and $2.8 \%$ soluble fiber), and can be considered essentially an energy-rich food given its high starch content (60.5\%), of which $85.04 \%$ was analyzed as amylopectin; it also showed a high potassium content $(19.09 \mathrm{mg} / \mathrm{g})$. The anti-nutritional component analysis showed low levels of oxalate $(5.55 \mathrm{mg} / \mathrm{g})$, saponins $(0.10 \%)$ and tannins $(0.07 \%)$, while phytates were not detected. The flour had a high water and oil absorption capacity $\left(9-11 \mathrm{~g} / \mathrm{g}\right.$ at 90 and $\left.100{ }^{\circ} \mathrm{C} ; 1.2 \mathrm{~g} / \mathrm{g}\right)$ and it gelatinized at between $81.81-89.58{ }^{\circ} \mathrm{C}$. It was also microbiologically stable after storage for 9 months at room temperature. Development of a multipurpose flour from cocoyam corm could provide a value-added option for the local food industry.
\end{abstract}

Keywords: Corm flour; Xanthosoma spp.; nutritional composition; functional properties.

Practical Application: Characterization of cocoyam corm flour demonstrates its potential use as ingredient in food industry. Cocoyam flour nutritional value, microbiological stability, and physicochemical and functional properties are favorably comparable to commercially available flours. Cocoyam flour is a good source of dietary fiber and its incorporation in food industry represents a great value-added alternative for this type of crop.

\section{Introduction}

Cocoyam (Xanthosoma spp.), the preferred root crop in Puerto Rico (Cortés \& Gayol, 2009), has experienced declining production in recent years (United States Department of Agriculture, 2012). Annual production in 2012 was about 15,993 qq, which only supplied approximately $19 \%$ of local consumption (Cortés \& Gayol, 2009). This decline is mainly attributed to common diseases that affect this crop, the most detrimental being known as "mal seco" due to its agricultural and economical repercussion (Estación Experimental Agrícola, 1997). Despite remaining a persistent condition, many of the limitations imposed by mal seco were overcome by the development of a new cultivar in Puerto Rico, which was named Nazareno. The present research sought to take advantage not only of the usually edible part of the plant (cormel), but also the corm or main stem (part discarded as waste or used as propagation material).

There are no public statistics currently available on the use of corms from the Nazareno cultivar in Puerto Rico, which suggests that this material is being wasted. At present, the only likely food application would be its incorporation in to the dough used in elaboration of a typical Puerto Rican dish known as "Pasteles" (similar to tamales). In some South Pacific and African countries, cocoyam corm is eaten as puree, roasted or boiled, either alone or combined with other ingredients, or added in soups as a thickening agent (Owusu-Darko et al., 2014).

Cocoyam corm has a high carbohydrate content (70 - 88\% on dry basis), principally in the form of starch (Bradbury \& Holloway, 1988; Onwueme \& Charles, 1994), which not only imparts desirable functional properties to foods, but also provides energy and promotes satiety in consumers (Owusu-Darko et al., 2014). Therefore, cocoyam corm could be considered as an alternative to others starchy vegetables (i.e. sweet potato, yam, or plantain), potentially turning it into a raw material of choice for the elaboration of a wide range of products in the food industry.

Despite the great nutritional potential of cocoyam corm obtained from the Nazareno cultivar, its utilization is not economically feasible unless it is first processed to reduces its high calcium oxalate levels (a characteristic of most cultivars of the Xanthosoma genre). This compound adversely affects the corm palatability, conferring acridity and a bitter-astringent taste (Owusu-Darko et al., 2014; Sefa-Dedeh \& Agyir-Sackey, 2004). Furthermore, this component possesses anti-nutritional and toxic properties, which represent a health hazard for humans when consumed in high concentrations (Bsc, 1999). 
In order to overcome the adverse effects caused by high oxalate contents, numerous methodologies have been developed to reduce or eliminate this substance, which include cooking, soaking, oven drying, sun drying, and fermentation (Igbabul et al., 2014; Iwuoha \& Kalu, 1995; Bsc, 1999; Sefa-Dedeh \& Agyir-Sackey, 2004). Several pertinent studies are available in the literature, Coronell-Tovar (2015) conducted preliminary work on three methods for oxalate reduction (water soaking, sun drying, and cooking) in cocoyam corm from the Nazareno cultivar. The most efficient method was found to be water soaking for 72 hours at $28{ }^{\circ} \mathrm{C}$ under constant shaking, which achieved a $77 \%$ relative reduction.

In order to evaluate the potential application of cocoyam corm flour in the food industry, it is of fundamental importance to understand its physical, chemical, functional, rheological, and microbiological properties, which determine the quality of the final product. The present study proposes the elaboration of cocoyam corm-based multi-purpose flour from the Nazareno cultivar, and demonstrates its potential usefulness in the food industry through its characterization. Hopefully the cocoyam corm might become a value-added product, and hence, an economically feasible alternative for local cocoyam farmers.

\section{Materials and methods}

\subsection{Raw material processing}

Cocoyam (Xanthosoma spp.) corms were harvested at the age of 10 months in the Agricultural Experiment Station at Isabela, $\mathrm{PR}$, and transported for further processing to the pilot plant of the Food Science and Technology Program at the University of Puerto Rico - Mayagüez Campus. Two hundred corms (raw material) were washed with water to eliminate soil particles and dirtiness, and then immersed in a 200 ppm solution of sodium hypochlorite for 15 minutes. Each corm length was measured and cut into 3 equal sections; apical, middle, and distal. The latter was discarded since this is the part with the highest oxalate content and, hence, of greater acridity (Coronell-Tovar, 2015). Corm peel and thick skin layer (corm pulp outer layer of approximately $5 \mathrm{~mm}$ thickness) were removed and the pulp was sliced with a food processor. Sample slices were washed with water and then dried at $40{ }^{\circ} \mathrm{C}$ for $24 \mathrm{~h}$ in dehydrators. Dried samples were ground and packaged in low density polyethylene bags.

\subsection{Elaboration of the cocoyam corm flour}

Flour was produced in a large-scale process which achieved the same oxalate reduction level of $77 \%$ as previously obtained with lab scale-methods. After drying, samples were soaked in distilled water $\left(100 \mathrm{~g}\right.$ of corm/L) for $72 \mathrm{~h}$ at $28^{\circ} \mathrm{C}$. In order to maximize flour yield, three types of equipment were used: (1) a bioreactor (BioFlo/CelliGen 115, New Jersey, USA), (2) a vacuum tumbler (Lance LT5, Pennsylvania, USA), and (3) Erlenmeyer flasks placed on stirring plates in an incubator (VWR Dry Incubator 1545, Oregon, USA). After $72 \mathrm{~h}$, the suspension was filtered, washed three times with distilled water and dried at $40{ }^{\circ} \mathrm{C}$ for $24 \mathrm{~h}$ in dehydrators. Rinse water from each sample was refrigerated for two days at $4{ }^{\circ} \mathrm{C}$ to allow the precipitation of leached starch. Starch was recovered by decantation and dried at $40{ }^{\circ} \mathrm{C}$ for $24 \mathrm{~h}$. Flour was obtained by grinding the corm and recovered starch using a mill with a screw drive and sieved through a 60 mesh. Afterwards, the corm was packed using a vacuum sealing system in highly in oxygen and moisture resistant bags, and stored in cardboard boxes at room temperature.

\subsection{Physical properties of the flour}

The water activity $\left(\mathrm{a}_{\mathrm{w}}\right)$, bulk density (BD), true density (TD), porosity, and color parameters (L, a, b and whiteness index) were determined. Water activity was measured using an Aqua Lab device (Decagon Devices 4 TE, Washington, USA). Bulk density, true density, and porosity were measured according to the method described by Hsu et al. (2003). Color parameters were evaluated by measuring the hunter L (luminosity $=0-100)$, a ( $+\mathrm{a}=\mathrm{red}$, $-\mathrm{a}=$ green $), \mathrm{b}(+\mathrm{b}=$ yellow, $-\mathrm{b}=$ blue $)$ scale. The colorimeter (Hunter Lab MiniScan XE, Virginia, USA) was configured for the illuminant D65 and 10 degrees' observer. Whiteness index (WI) was calculated according to the equation proposed by Hsu et al. (2003) $\left(\mathrm{WI}=100-\sqrt{(100-L)^{2}+a^{2}+b^{2}}\right)$.

\subsection{Chemical properties}

Moisture content, ash, crude protein ( $\mathrm{N}$ x 6.25), lipids and crude fiber were determined according to the Association of Official Analytical Chemists (2003) and American Oil Chemists' Society (2009) methods. The nitrogen-free extract (NFE) was estimated by difference. Dietary fiber, soluble fiber, and insoluble fiber were determined according to the AOAC 991.43 procedure with slight modifications in the filtration process (Celite bed was placed over filter paper on a fritted glass crucible). Flour $\mathrm{pH}$ was measured by AOAC 943.02 method. Reducing sugars content was determined by Lane-Eynon general volumetric method described in AOAC 923.09 procedure (Association of Official Analytical Chemists, 2003).

Starch analysis involved, first hydrolysis carried out according to Vatanasuchart et al. (2012) and second quantification by the method of Sadasivam \& Manickam (1996). Six mL of $2 \mathrm{M} \mathrm{KOH}$ were added to $50 \mathrm{mg}$ of corm flour. After 30 minutes, solubilized starch was hydrolyzed using $60 \mu \mathrm{L}$ of amyloglucosidase, followed by incubation at $60{ }^{\circ} \mathrm{C}$ for 45 minutes in a shaking water bath. Samples were refrigerated at $5{ }^{\circ} \mathrm{C}$ to promote residue precipitation. The glucose content in the supernatant was measured spectrophotometrically using the phenol-sulfuric acid method.

For amylose and amylopectin determination, samples were prepared according to Simsek et al. (2013) and quantified by high-performance size-exclusion chromatography (HPSEC) following the Yoo \& Jane (2002) procedure in which molecular weight also was recorded. An HPSEC (Agilent Technologies 1200 series, California, USA) equipped with multi-angle laser-light scattering (Wyatt Dawn Heleos II, California, USA) and refractive index detectors was used. The chromatographic separation was carried out on a guard column, a linear size exclusion column and a homogeneous particle size column (Waters, Tokyo, Japan) using an isocratic elusion at $0.7 \mathrm{~mL} / \mathrm{min}$ with deionized water $(18.2 \mathrm{M} \Omega \mathrm{cm})$ as mobile phase. The temperature of the injector and columns was set to $55^{\circ} \mathrm{C}$, whereas that of the refractive index detector was set to $30^{\circ} \mathrm{C}$. 
Mineral content (Ca, Mg, K, Na, B, Cu, Fe, Mn, Mo, P, and S) was measured according to the method of Perkin-Elmer (1994) using an inductively coupled plasma-optical emission spectrometer (PE 7300 DV, Massachusetts, USA).

\subsection{Anti-nutritional factors}

Oxalate content was analyzed using the volumetric procedure defined by Iwuoha \& Kalu (1995) with minor modifications. This method involves three steps: acid digestion, oxalate precipitation, and permanganometric titration. Flour- $0.3 \mathrm{~N} \mathrm{HCl}$ suspensions $(1: 100 \mathrm{w} / \mathrm{v})$ were heated under reflux for 1 hour, cooled and diluted with deionized water to a final volume of $250 \mathrm{~mL}$ before filtration. After addition of $1 \%$ methyl red to an aliquot of filtrate, concentrated $\mathrm{NH}_{4} \mathrm{OH}$ solution was added dropwise until an observable color change from salmon pink to faint yellow was detected. The solution was heated at $90{ }^{\circ} \mathrm{C}$, cooled, filtered, and received an addition of $10 \% \mathrm{CaCl}_{2}$ at $90^{\circ} \mathrm{C}$. After heating, the solution was cooled at $5{ }^{\circ} \mathrm{C}$ for $12-14$ hours, and then centrifuged at 3,000 rpm for $5 \mathrm{~min}$. The oxalate precipitate was dissolved in a $20 \%(\mathrm{v} / \mathrm{v})$ boiling sulfuric acid solution and titration was carried out with a $0.05 \mathrm{~N}$ standardized $\mathrm{KMnO}_{4}$ solution by heating $10 \mathrm{~mL}$ aliquot from the acid solution (dissolved precipitate) at $70-80^{\circ} \mathrm{C}$.

Saponin content was determined according to the gravimetric method described by Igbabul et al. (2014). Phytate and tannin contents were analyzed employing the volumetric method defined by Akinmutimi (2006) and Atanassova \& Christova (2009), respectively.

\subsection{Functional properties}

Water absorption capacity and water solubility index were measured according to the method described by Aboubakar et al. (2008). Oil absorption and emulsifying capacities were determined by the procedure of Rodríguez et al. (2011).

\subsection{Gelatinization and pasting profile}

Gelatinization profile was determined by differential screening calorimetry (DSC Q200, Delaware, USA) in a 20\% aqueous suspension (w/w on dry basis) according to the method described in American Society for Testing and Materials (2008). Heating rate was $10{ }^{\circ} \mathrm{C} / \mathrm{min}$ and temperature range was $20-100{ }^{\circ} \mathrm{C}$. The initial temperature, maximum peak temperature, final temperature, and gelatinization enthalpy were obtained from the thermogram.

Pasting profile was determined using a rheometer (AR 1500ex, Delaware, USA) in an $8 \%$ aqueous suspension (w/w on dry basis) following the methods of Bastioli (2005) and International Association for Cereal Science and Technology (1996). Pasting temperature, peak viscosity, breakdown, setback, and consistency (total setback) were calculated based on the pasting curve.

\subsection{Microbiological analysis}

Fluor microbiological stability during 9 months of storage was determined using the methods outlined by AOAC for aerobic count plate (AOAC 990.12), of Escherichia coli/Coliforms (AOAC 991.14), and yeasts and molds (AOAC 997.02) (Association of Official Analytical Chemists, 2003).

\subsection{Statistical analysis}

All the described parameters were measured nine times $(n=9)$, except for those of oxalate, amylose, amylopectin, gelatinization, and pasting profiles $(n=3)$. Results were expressed as means with their respective standard errors. The statistical analysis comprised an analysis of variance (ANOVA) and Tukey Test at the $5 \%$ level of confidence using InfoStat (Rienzo et al., 2014).

\section{Results and discussion}

\subsection{Physical properties}

Table 1 present results regarding physical properties of the flour. A slight but significant difference was found between the two sections of cocoyam corm in bulk density, being lower in the middle than the apical section $(0.73$ vs. $0.75 \mathrm{~g} / \mathrm{mL})$. No statistical difference was found in terms of porosity. In contrast with common food powders, whose bulk and true densities range from $0.20-0.96 \mathrm{~g} / \mathrm{mL}$ and $0.90-2.16 \mathrm{~g} / \mathrm{mL}$, respectively (Ibarz \& Barbosa-Canovas, 2014), the variation between these parameters in cocoyam corm flour is not very marked due to its low porosity.

The water activity $\left(\mathrm{a}_{\mathrm{w}}\right)$ values for both cocoyam corm sections (apical $=0.39$, middle $=0.37$ ) were low and statistically equal. For this reason, the flour can be considered "safe and stable" from the microbiological standpoint. The small quantity of available water in this flour limits the proliferation of pathogens and spoilage microorganisms.

A significant difference was found in color parameters ( $L, a, b$, and whiteness index) between the two sections of cocoyam corm, all four parameters being lower in the apical $(\mathrm{L}=62.44, \mathrm{a}=3.35, \mathrm{~b}=9.38, \mathrm{WI}=61.13)$ than the middle section $(\mathrm{L}=67.75, \mathrm{a}=3.55, \mathrm{~b}=11.46, \mathrm{WI}=65.58)$. The WI value can be interpreted to reflect the influence of compounds that impart color (such as terpenes and flavonoids), since the flour presented a low luminosity value $(\bar{L}=65.10)$ and a positive shift in both $a$ (red) and $b$ (yellow) scales. The mean WI for both corm sections was 63.36 which is lower than literature values for flours

Table 1. Physical properties of cocoyam corm flour.

\begin{tabular}{|c|c|c|c|c|c|c|c|c|}
\hline \multirow{2}{*}{ Sample } & \multirow{2}{*}{ Bulk density (g/mL) } & \multirow{2}{*}{ True density (g/mL) } & \multirow{2}{*}{ Porosity } & \multirow[b]{2}{*}{$\mathrm{a}_{\mathrm{w}}$} & \multicolumn{4}{|c|}{ Color } \\
\hline & & & & & $\mathrm{L}$ & $\mathrm{a}$ & $\mathrm{b}$ & Whiteness Index \\
\hline Apical & $0.75 \pm 0.01^{\mathrm{a}}$ & $0.95 \pm 0.01^{\mathrm{a}}$ & $0.21 \pm 0.00^{\mathrm{a}}$ & $0.39 \pm 0.01^{\mathrm{a}}$ & $62.44 \pm 0.58^{\mathrm{a}}$ & $3.35 \pm 0.04^{\mathrm{a}}$ & $9.38 \pm 0.08^{\mathrm{a}}$ & $61.13 \pm 0.55^{\mathrm{a}}$ \\
\hline Middle & $0.73 \pm 0.01^{\mathrm{b}}$ & $0.92 \pm 0.01^{\mathrm{b}}$ & $0.21 \pm 0.00^{\mathrm{a}}$ & $0.37 \pm 0.01^{\mathrm{a}}$ & $67.75 \pm 0.58^{\mathrm{b}}$ & $3.55 \pm 0.04^{\mathrm{b}}$ & $11.46 \pm 0.08^{\mathrm{b}}$ & $65.58 \pm 0.55^{\mathrm{b}}$ \\
\hline
\end{tabular}

Values are expressed as means \pm standard error. Means in the same column with common letters are not significantly different $(\mathrm{p}>0.05)$. 
of Xanthosoma. saggitifolium (83.30) and Colocasia esculenta (78.17 - 88.87) (Aboubakar et al., 2008; Pérez et al., 2007; Rodríguez et al., 2011). Nevertheless, this lower WI does not necessarily denote an objectionable attribute of the flour because its use will depend not only on consumer acceptance, but also on the particular applications established by the food industry. However, this characteristic could limit utilization of the flour in products that do not require the impartation of color.

\subsection{Chemical composition}

Chemical composition of the flour is shown in Table 2. The main component was NFE in the flour from both corm sections. This analytical fraction is principally constituted by carbohydrates (starch being the most abundant). The second and third most abundant fractions were dietary fiber, and crude protein respectively. Lipid and ash were minority compounds in the flour. Upon comparing the proximate composition of flour from corm apical and middle sections (Table 2), only ash and crude protein content show a statistical difference. Cocoyam corm flour from both sections gave a mean moisture content of $6.56 \%$, which is favorable for its storage at room temperature, since this low water availability is not suitable for microbial growth. Thus, this is a safe product for the consumer and with a long shelf-life.

The most abundant mineral found in cocoyam corm flour by a wide margin was potassium. Therefore, it represents a good source of this mineral, since $100 \mathrm{~g}$ of cocoyam flour would provide $55 \%$ of the daily potassium requirement for adults and children of four or more years of age $(3,500 \mathrm{mg})$.

Although the protein content found in cocoyam corm flour $(9.74 \%)$ is not outstanding in comparison to some other roots and tubers (Odebunmi et al., 2007), it could be improved if necessary by adding other protein sources to the flour.

Starch, as major component in the flour, plays an important role due to its versatility. This polysaccharide confers functional characteristics typical of starchy foods, which influence significantly organoleptic properties particularly about texture (Espín et al., 2004).

Dietary fiber was found to be the second most abundant component in cocoyam corm flour and was significantly higher in the middle section (19.74\%) than in the apical portion (17.50\%).

Table 2. Chemical characterization of the corm flour (on dry basis).

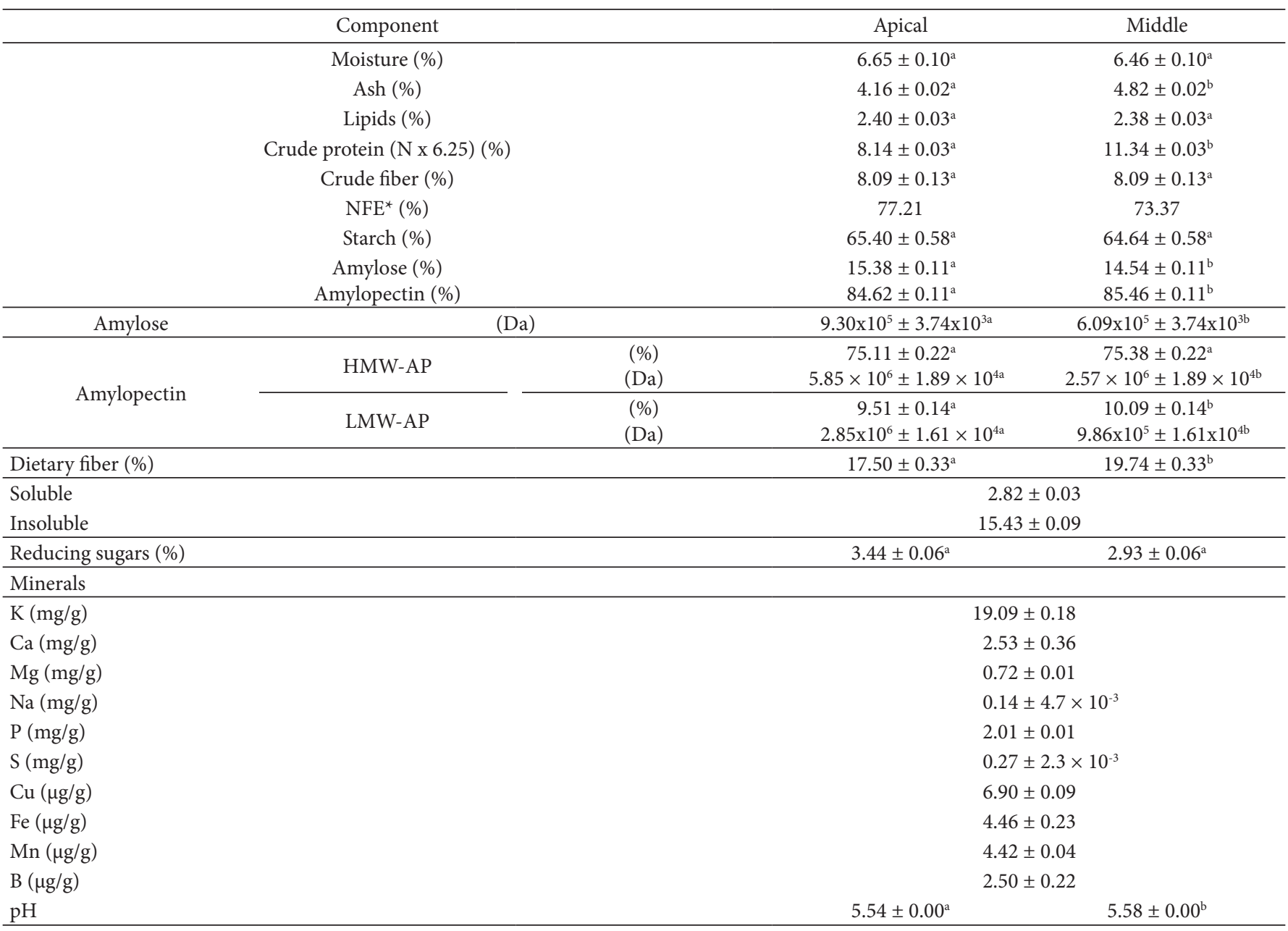

${ }^{*}$ Calculated by difference ( 100 - proteins - ashes - fibers - lipids - moisture); Values are expressed as means \pm standard error. Means in the same row with common letters are not significantly different ( $\mathrm{p}>0.05$ ); Amylose and amylopectin content was calculated on $100 \%$ base of total starch; HMW-AP is high molecular weight - amylopectin; LMW-AP is low molecular weight - amylopectin. 
This confers to the flour an important health promoting value, since the consumption of foods high in dietary fiber content such as whole cereals $(0.7-17.3 \%)$, fruits $(0.5-3.39 \%)$, vegetables $(0.6-16.6 \%)$ and nuts $(6-22.33 \%)$ is associated with a lower incidence of certain health disorders (Dhingra et al., 2012). Subdivision of the total fiber contained in the flour between two fractions, showed the insoluble portion to be 12.61 percentage points higher than the soluble fraction. Moreover, the crude fiber fraction in the flour was lower than the dietary fiber. This concurs with expectation given that the macromolecules comprising the crude fiber are partially degraded during the sequential alkaline and acidic hydrolysis in the analytical procedure, leading to an underestimate of their concentration.

Reducing sugars were found to be a minority component in the flour. The importance of this information is that the reducing sugars content should correlate with the susceptibility of the starch to chemical or enzymatic hydrolysis during the soaking process (Aboubakar et al., 2008). The low reducing sugars value $(3.19 \%)$ in the flour suggests that the starch does not present a high susceptibility to hydrolysis.

Flour $\mathrm{pH}$ was slightly acidic (5.56), which was to be expected considering that the soaking process favors production of organic acids by chemical hydrolysis or enzymatic activity of indigenous microflora from the corm. Although flour $\mathrm{pH}$ is not low enough to inhibit microbial proliferation during storage $(\mathrm{pH}<4.6)$, the product should still be microbiologically stable given its low $\mathrm{a}_{\mathrm{w}}$ value (0.38).

\section{Amylose and amylopectin}

Zhu (2016) reported amylose values for Xanthosoma spp. starches ranging from $15-35 \%$. In the present results, the proportions of amylose and amylopectin in cocoyam flour were $14.96 \%$ and $85.04 \%$ respectively, with a significant statistical difference between them (Table 2). This amylose percentage in cocoyam flour corresponds to the lowest value reported in the literature. However, the estimated amylose content may vary depending on the quantification procedure employed (Lu et al., 2008). For this reason the discrepancies in question may not be solely due to inherent differences among species varieties or cultivars. In the present study, the amylose content was determined by HPSEC, while the other authors employed differential scanning calorimetry, colorimetry, potentiometry or amperometry using iodine (Zhu, 2016).

Taking into account that the content of high molecular weight amylopectin was greater than that of low molecular weight amylopectin, it is to be expected that the corm flour would present a high gelatinization temperature, since it takes a greater amount of energy to dissociate the high molecular weight amylopectin chains (Tan \& Halley, 2014).

The molecular weights of amylose and amylopectin determined in both corm sections differed significantly, being higher in the apical portion than in the middle section. This suggests that although the starch, might be extracted from the same raw material, it can still present variations in terms of the amylose/amylopectin ratio as well as molecular weight throughout the corm.

\subsection{Anti-nutritional factors}

The corm flour presented a low content of anti-nutrients (Table 3), which can be ascribed to the high water solubility of these components (Igbabul et al., 2014; Olajide et al., 2011). Therefore, corm flour does not constitute a major health hazard in this regard, making it suitable for human consumption. Moreover, in the present study the concentration of phytates in the flour was too low to be detected. This is certainly a positive finding, since this anti-nutrient has been found in aroids flour, even though the pulp was soaked in water for $72 \mathrm{~h}$ (Igbabul et al., 2014; Olajide et al., 2011).

Regarding the anti-nutrient oxalate (Table 3), the apical section had a lower content than in the middle section ( 5.08 vs. $6.02 \mathrm{mg} / \mathrm{g}$ ); both values being lower than one detected for the cormel flour $(8.53 \mathrm{mg} / \mathrm{g})$. These results support inclusion of the corm flour in the human diet just as well as the cormel, which is widely consumed in Puerto Rico. Furthermore, occasional consumption of cocoyam corm flour, just as in the case of other foods high in oxalate content, such as spinach $(3.20-12.60 \mathrm{mg} / \mathrm{g})$, rhubarb $(2.75-13.36 \mathrm{mg} / \mathrm{g})$, purslane $(9.10-16.79 \mathrm{mg} / \mathrm{g})$, and cocoa (5.00 - $9.00 \mathrm{mg} / \mathrm{g}$ ), among others, does not represent a health concern as long as it is ingested as part of a balanced diet (Bsc, 1999).

\subsection{Water absorption capacity, water solubility index, oil absorption capacity, and emulsifying capacity}

Oil absorption capacity was statistically different between flour from the two sections of the corm, being slightly higher in the middle than the apical section (1.34 vs.1.13 g/g) (Table 4). This variation could be attributed to a higher protein content in the middle section, in view of known interaction between lipids and hydrophobic lateral protein chains. The mean oil absorption capacity determined in the cocoyam corm flour was $1.23 \mathrm{~g} / \mathrm{g}$, which is in concordance with values reported in literature for C. esculenta flour, after soaking the pulp in water for $72 \mathrm{~h}(1.14 \mathrm{~g} / \mathrm{g})$ (Igbabul et al., 2014) and for $24 \mathrm{~h}(1.20 \mathrm{~g} / \mathrm{g})$ (Iwuoha \& Kalu, 1995). Given its good oil absorption capacity,

Table 3. Anti-nutritional components in cocoyam corm flour.

\begin{tabular}{ccc}
\hline Anti-nutrient & Apical & Middle \\
\hline Oxalate $(\mathrm{mg} / \mathrm{g})$ & $5.08 \pm 0.01^{\mathrm{a}}$ & $6.02 \pm 0.01^{\mathrm{b}}$ \\
Saponins $(\%)$ & $0.10 \pm 0.00^{\mathrm{a}}$ & $0.10 \pm 0.00^{\mathrm{a}}$ \\
Tannins $(\%)$ & $0.07 \pm 0.00^{\mathrm{a}}$ & $0.07 \pm 0.00^{\mathrm{a}}$ \\
\hline
\end{tabular}

Values are expressed as means \pm standard error. Means in the same row with common letters are not significantly different $(\mathrm{p}>0.05)$.

Table 4. Oil absorption capacity (OAC) and emulsifying capacity (EC) of cocoyam corm flour.

\begin{tabular}{ccc}
\hline Sample & OAC $(\mathbf{g}$ of oil/g of flour $)$ & EC $(\%)$ \\
\hline Apical & $1.13 \pm 0.01^{\mathrm{a}}$ & $5.33 \pm 0.04^{\mathrm{a}}$ \\
Middle & $1.34 \pm 0.01^{\mathrm{b}}$ & $5.53 \pm 0.04^{\mathrm{b}}$ \\
\hline
\end{tabular}

Values are expressed as means \pm standard error. Means in the same column with common letters are not significantly different $(\mathrm{p}>0.05)$. 
the incorporation of cocoyam corm flour can be recommended in confections, in which oil absorption is fundamental for imparting specific organoleptic properties. On the contrary, the corm flour of both sections showed a low emulsifying capacity of $5.43 \%$ (Table 4), which is below the value found for C. esculenta flour (37.92 \%) (Rodríguez et al., 2011). Low emulsifying capacity of corm flour is due to the low solubility of the corm proteins and/or their low capacity to orient at the oil-water interphase. Hence, this product could not be used in products that require the formation of stable emulsions.

Measurements of water absorption capacity and water solubility index at high temperatures are essential in the food industry because many preparations require hydrothermal treatments (soups, creams, sauces, compotes, and confectionery products, among others). According to the present results, water absorption capacity and water solubility index of both the middle and apical corm flours presented the same increasing tendency during the hydrothermal treatment. Figure 1 shows the pattern of these properties as a function of temperature, in which a significant increase of both parameters is noted ( $\mathrm{p}<0.0001)$. This is in agreement with the reported behavior of C. esculenta starches and flours (Aboubakar et al., 2008). The increment in water absorption capacity is attributed to the formation of additional hydrogen bonds between water molecules and amylose and amylopectin chains. High temperatures cause dissociation of intermolecular hydrogen bonds from the starch granules, thus promoting water diffusion into them (Bao \& Bergman, 2004; Hoover, 2001).

Gunaratne \& Hoover (2002) described the water absorption capacity for yam, giant taro, cassava, potato, and cocoyam starches as directly proportional to the amount of leached amylose as well as to the solubility, which results in loss of the crystalline structure of the native starch granules. In the case of cocoyam corm flour, a significant correlation was found between the water absorption capacity and the solubility index $(\mathrm{r}=0.97, \mathrm{p}<0.0001)$. The observed increment of solubility with increasing temperature is logical since at higher temperatures, the level of soluble solids will increase due to exposure of the hydrophilic groups resulting from breakage of starch granules (Aboubakar et al., 2008; Hoover, 2001).

\subsection{Gelatinization and pasting properties}

Table 5 shows gelatinization and pasting profiles for the corm flour. Gelatinization temperature of this product was found to be high, thus confirming the hypothesis that given the elevated content of high molecular weight amylopectin, more energy will be required to dissociate the chains. Despite the great proportion of high molecular weight amylopectin observed in the starch of the corm flour, its gelatinization enthalpy $(\Delta H)$ (corresponding to the energy necessary to complete the process) was low. This may

Table 5. Gelatinization and pasting profiles of the cocoyam corm flour by rheology and thermal analysis.

\begin{tabular}{lccc}
\hline \multirow{2}{*}{ Parameter } & \multicolumn{2}{c}{ Equipment } \\
\cline { 2 - 4 } & Initial $\left(\mathrm{T}_{\mathrm{i}}\right)$ & $83.60 \pm 0.58$ & $81.82 \pm 0.52$ \\
Gelatinization & Middle $\left(\mathrm{T}_{\mathrm{m}}\right)$ & ---- & $85.02 \pm 0.58$ \\
temperature $\left({ }^{\circ} \mathrm{C}\right)$ & Final $\left(\mathrm{T}_{\mathrm{f}}\right)$ & ---- & $89.58 \pm 0.64$ \\
& & $78.76 \pm 0.52$ & ---- \\
Peak viscosity $\left(\mathrm{RVU}^{*}\right)$ & $76.46 \pm 0.52$ & ---- \\
Minimum viscosity $(\mathrm{RVU})$ & $113.9 \pm 1.15$ & ---- \\
Final viscosity $(\mathrm{RVU})$ & $2.30 \pm 0.01$ & ---- \\
Breakdown $(\mathrm{RVU})$ & $35.14 \pm 0.64$ & ---- \\
Setback $(\mathrm{RVU})$ & $37.44 \pm 0.63$ & ---- \\
Consistency $(\mathrm{RVU})$ & ---- & $5.00 \pm 0.05$ \\
Enthalpy $\Delta \mathrm{H}(\mathrm{J} / \mathrm{g})$ & & & \\
\hline
\end{tabular}

${ }^{\star} 1 \mathrm{RVU}=0.01$ Pa.s, $720 \mathrm{BU}=170 \mathrm{RVU}, 1$ Pa.s $=1000 \mathrm{cP}$; Values are expressed as means \pm standard error $(n=3)$; Breakdown = Peak viscosity - minimum viscosity; Setback = Final viscosity - peak viscosity; Consistency $=$ Final viscosity - minimum viscosity.

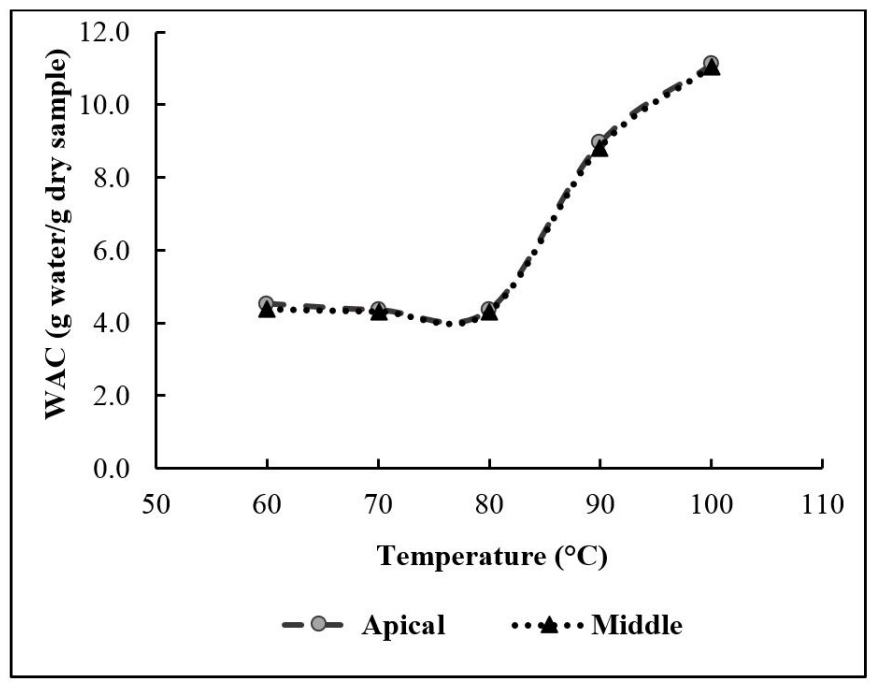

a)

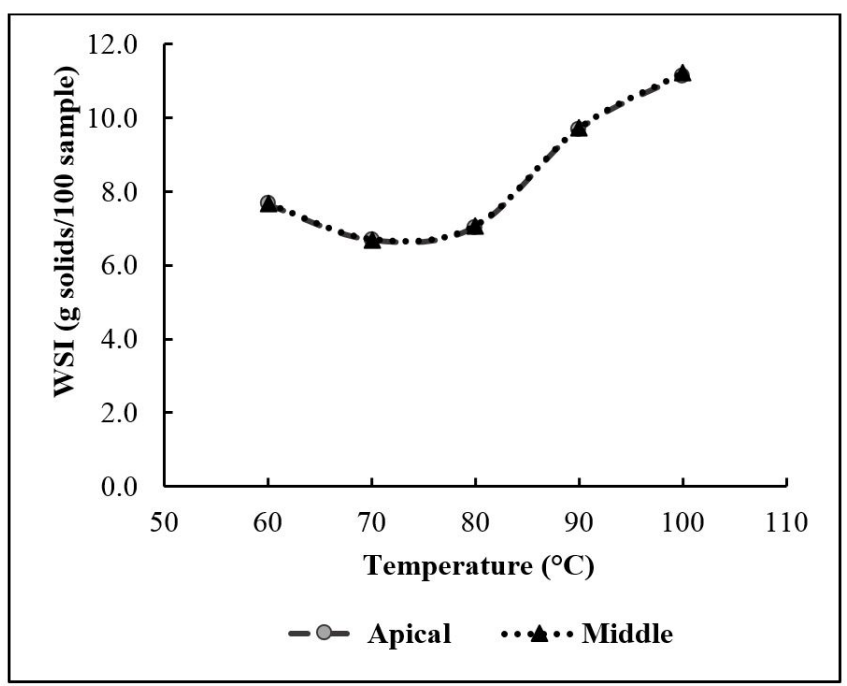

b)

Figure 1. Functional properties of cocoyam corm flour: a) water absorption capacity (WAC) and b) water solubility index (WSI). 
be attributed to rather weak interactions between amylopectin double helices (Gunaratne \& Hoover, 2002). These results support the concept that gelatinization profile is determined not only by the molecular structure of amylopectin (chains length, ramification), but also by its composition (amylose/amylopectin ratio, non-starchy components, such as proteins, lipids, minerals, and fiber) and by structure of the starch granules (proportion of crystalline and amorphous areas) (Gunaratne \& Hoover, 2002).

The present gelatinization profile of cocoyam corm flour obtained by DSC differs from that reported for X. saggitifolium $\left(T_{i}-T_{f}=85.2-103.3^{\circ} \mathrm{C}, \Delta H=9.80 \mathrm{~J} / \mathrm{g}\right)$ (Pérez et al., 2007), all parameters being lower for cocoyam. On the other hand, cocoyam corm flour exhibited a higher gelatinization temperature and a lower enthalpy than reported values for C. esculenta flours of $T_{i}=55.20-65.49^{\circ} \mathrm{C}, T_{f}=61.24-73.33^{\circ} \mathrm{C}$ and $\Delta H=8.43-14.95 \mathrm{~J} / \mathrm{g}$ (Aboubakar et al., 2008). Gelatinization temperature range reported by Pérez et al. (2007) $\left(79.5-94.3^{\circ} \mathrm{C}\right)$ was comparable with that of cocoyam corm flour, whereas gelatinization enthalpy found by those authors $(9.80 \mathrm{~J} / \mathrm{g})$ was higher than the present value for cocoyam corm flour.

Upon comparing pasting profile values of corm flour with those reported in the literature, its gelatinization temperature is similar to that of C. esculenta $\left(82.5^{\circ} \mathrm{C}\right)$ but higher than the value found for $\mathrm{X}$. sagittifolium $\left(78^{\circ} \mathrm{C}\right.$ ) (Pérez et al., 2007).

Since corm flour possesses a high gelatinization temperature, its use can be recommended for products that require high processing temperatures, such as canned foods (Hernández-Medina et al., 2008).

Corm flours peak viscosity (78.76 RVU) observed during heating and mechanical treatment suggests a product with lower thickening capacity compared to the more viscous aroid flours from the genera Colocasia (98.96 - $441 \mathrm{RVU}$ ) and Xanthosoma (97.25 - 323.5 RVU) (Coronell-Tovar, 2015).

Flour breakdown value was low ( $2.30 \mathrm{RVU})$ showing that the paste is highly stable during heating and shaking. On the other hand, the setback value (35.14 RVU) revealed that the final viscosity after cooling is higher than the peak viscosity during heating, indicating that the paste is not stable during cooling. Therefore, it is necessary to take into account this tendency when deciding whether the flour should be used as an ingredient in a given formulation.

\subsection{Microbiological stability}

The number of colony-forming units per gram (CFU/g) of mesophilic aerobics and yeasts in flours of apical and middle corn sections during 9 months of storage (apical $=5.27 \mathrm{Log} \mathrm{CFU} / \mathrm{g}$, middle $=\log 4.31 \mathrm{CFU} / \mathrm{g})$ were statistically different $(\mathrm{p}<0.05)$. This can perhaps be attributed to slight variations in their chemical compositions such as a higher initial water content in fresh cocoyam corm pulp of the apical portion.

The aerobic counts in corm flour were within the range reported by Nguyen \& Carlin (2000) for dehydrated vegetables (leafy greens, roots, tubers, stems, and bulbs), in which values oscillated between 1 and $8 \mathrm{Log}$ CFU/g. The coliform and E. coli counts in the flour were below $1 \mathrm{Log} \mathrm{CFU} / \mathrm{g}$, which is favorable considering that the presence of this type of microorganism is usually associated with poor sanitation practices. Mold levels were also under $1 \log \mathrm{CFU} / \mathrm{g}$, which was anticipated, given that the most xerophilic molds require a minimum $\mathrm{a}_{\mathrm{w}}$ of 0.61 to proliferate (Nguyen \& Carlin, 2000). Yeasts counts (apical $=5.11 \mathrm{Log}$ CFU/g, middle $=4.44 \mathrm{Log} \mathrm{CFU} / \mathrm{g}$ ) in the flours were lower than those reported by Nguyen \& Carlin (2000) for dehydrated vegetables $(<8$ Log UFC/g).

Cocoyam corm flour was microbiologically stable during storage for 9 months, since there were no statistical differences in the aerobic, coliforms, E. coli, mold and yeast counts with respect to time. This could be attributed to the intrinsic properties of cocoyam corm flour, such as its low $\mathrm{a}_{\mathrm{w}}$ and low moisture content, and extrinsic factors such as temperature $\left(20-25^{\circ} \mathrm{C}\right)$, packaging in vacuum bags, and other storage conditions, which were not favorable for microbial proliferation.

\section{Conclusion}

Pre-soaked cocoyam corm flour from the Nazareno cultivar shows great potential for use as an ingredient in the food industry based on its nutritional value, microbiological stability and physicochemical and functional properties. Cocoyam flour is a good source of dietary fiber and potassium and may be useful when oil absorption capacity is necessary to impart desirable organoleptic properties to certain foods. Due to its high gelatinization temperature, the incorporation of this flour is recommended in products subjected to high processing temperatures. Flour elaboration from an agricultural residue such as the corm would represent a value-added alternative for the cocoyam crop harvested in Puerto Rico, with possible increased profitability for the farmer, while also expanding the available options of starchy foods for local consumers.

\section{Acknowledgements}

The research published in this article was conducted under Project ZFIDA-20, supported by the Department of Agriculture of Puerto Rico.

\section{References}

Aboubakar, N., Njintang, Y. N., Scher, J., \& Mbofung, C. M. F. (2008). Physicochemical, thermal properties and microstructure of six varieties of taro (Colocasia esculenta L. Schott) flours and starches. Journal of Food Engineering, 86(2), 294-305. http://dx.doi.org/10.1016/j. jfoodeng.2007.10.006.

Akinmutimi, A. H. (2006). Nutritive value of raw and processed jackfruit seeds (Artocarpus heterophyllus): chemical analysis. Agricultural Journal, 1(4), 266-271.

American Oil Chemists' Society - AOCS. (2009). Official methods and recommended practices of the AOCS (6th ed.). Champaign: AOCS Press.

American Society for Testing and Materials - ASTM. (2008). Standard test method for transition temperatures and enthalpies of fusion and crystallization of polymers by differential scanning calorimetry (ASTM D3418-08. Plastics II: D3222 - D5083, vol. 8.02). West Conshohocken: ASTM. 
Association of Official Analytical Chemists - AOAC. (2003). Official methods of analysis of the AOAC international (17th ed., 2nd rev., vol. II). Gaithersburg: AOAC.

Atanassova, M., \& Christova, V. (2009). Determination of tannins content by titrimetric method for comparison of different plant species. Journal of the University of Chemical Technology and Metallurgy, 44(4), 413-415.

Bao, J., \& Bergman, C. J. (2004). The functionality of rice starch. In A. C. Eliasson (Ed.), Starch in food: structure, function and applications (1st ed., pp. 269-277). Cambridge: CRC Press.

Bastioli, C. 2005. Starch-based technology. In C. Bastioli (Ed.), Handbook of biodegradable polymers (1st ed., pp. 257-286). Shawbury: Rapra Technology Limited.

Bradbury, J. H., \& Holloway, W. D. (1988). Antinutritional factors in root crops. The chemical composition of tropical root crops: significance for nutrition and agriculture in the pacific (chap. 5, pp. 101-119). Canberra: ACIAR.

Bsc, S. N. (1999). Oxalate content of foods and its effect on humans. Asia Pacific Journal of Clinical Nutrition, 8(1), 64-74. http://dx.doi. org/10.1046/j.1440-6047.1999.00038.x. PMid:24393738.

Coronell-Tovar, D. C. (2015). Elaboración de harina a partir del cormo de la yautía (Xanthosoma spp.) del cultivar Nazareno con potencial uso en la industria de alimentos (Master's dissertation). Programa de Ciencia y Tecnología de Alimentos, Universidad de Puerto Rico, Mayagüez, Puerto Rico.

Cortés, M., \& Gayol, L. (2009). Descriptive analysis of consumer preferences on tubers in Puerto Rico. The Journal of Agriculture of the University of Puerto Rico, 93(3/4), 273-276.

Dhingra, D., Michael, M., Rajput, H., \& Patil, R. T. (2012). Dietary fiber in foods: a review. Journal of Food Science and Technology, 49(3), 255266. http://dx.doi.org/10.1007/s13197-011-0365-5. PMid:23729846.

Espín, S., Villacrés, E., \& Brito, B. (2004). Caracterización físico química, nutricional y funcional de raíces y tubérculos andinos. In V. H. Barrera, C. G. Tapia \& A. R. Monteros (Eds.), Raíces y tubérculos andinos: alternativas para la conservación y uso sostenible en el Ecuador (pp. 91-116). Quito: International Potato Center.

Estación Experimental Agrícola - EEA. (1997). Conjunto tecnológico para la producción de raíces y tubérculos (Publicación 101). Puerto Rico: Estación Experimental Agrícola, Universidad de Puerto Rico.

Gunaratne, A., \& Hoover, R. (2002). Effect of heat-moisture treatment on the structure and physicochemical properties of tuber and root starches. Carbohydrate Polymers, 49(4), 425-437. http://dx.doi. org/10.1016/S0144-8617(01)00354-X.

Hernández-Medina, M., Torruco-Uco, J. G., Chel-Guerrero, L., \& Betancur-Ancona, D. (2008). Caracterización fisicoquímica de almidones de tubérculos cultivados en Yucatán, México. Food Science and Technology (Campinas), 28(3), 718-726. http://dx.doi. org/10.1590/S0101-20612008000300031.

Hoover, R. (2001). Composition, molecular structure, and physicochemical properties of tuber and root starches: a review. Carbohydrate Polymers, 45(3), 253-267. http://dx.doi.org/10.1016/S0144-8617(00)00260-5.

Hsu, C.-L., Chen, W., Weng, Y.-M., \& Tseng, C.-Y. (2003). Chemical composition, physical properties, and antioxidant activities of yam flours as affected by different drying methods. Food Chemistry, 83(1), 85-92. http://dx.doi.org/10.1016/S0308-8146(03)00053-0.

Ibarz, A., \& Barbosa-Canovas, G. V. (2014). Physical and chemical properties of food powders. In A. Ibarz, \& G. V. Barbosa-Canovas (Eds.), Introduction to Food Process Engineering (p. 261-287). Boca Raton: CRC Press. http://dx.doi.org/10.1201/b14969-16.
Igbabul, B. D., Amove, J., \& Twadue, I. (2014). Effect of fermentation on the proximate composition, antinutritional factors and functional properties of cocoyam (Colocasia esculenta) flour. African Journal of Food Science, 5(3), 67-74.

International Association for Cereal Science and Technology - ICC. (1996). Rapid pasting method using the newport rapid visco analyser (Standard Method No. 162). Vienna: ICC.

Iwuoha, C. I., \& Kalu, F. A. (1995). Calcium oxalate and physicochemical properties of cocoyam (Colocasia esculenta and Xanthosoma sagittifolium) tuber flours as affected by processing. Food Chemistry, 54(1), 61-66. http://dx.doi.org/10.1016/0308-8146(95)92663-5.

Lu, T.-J., Lin, J.-H., Chen, J.-C., \& Chang, Y.-H. (2008). Characteristics of taro (Colocasia esculenta) starches planted in different seasons and their relations to the molecular structure of starch. Journal of Agricultural and Food Chemistry, 56(6), 2208-2215. http://dx.doi. org/10.1021/jf0727894. PMid:18293922.

Nguyen, C., \& Carlin, F. (2000). Fresh and processed vegetables. In B. Lund, T. C. Baird-Parker \& G. W. Gould (Eds.), Microbiological safety and quality of food (vol. I, pp. 154-668). Gaithersburg: Aspen Publishers.

Odebunmi, E. O., Oluwaniyi, O. O., Sanda, A. M., \& Kolade, B. O. (2007). Nutritional compositions of selected tubers and root crops used in Nigerian food preparations. International Journal of Chemistry, 17(1), 37-43.

Olajide, R., Akinsoyinu, A. O., Babayemi, O. J., Omojola, A. B., Abu, A. O., \& Afolabi, K. D. (2011). Effect of processing on energy values, nutrient and anti-nutrient components of wild cocoyam (Colocasia esculenta L. Schott) corm. Pakistan Journal of Nutrition, 10(1), 29-34. http://dx.doi.org/10.3923/pjn.2011.29.34.

Onwueme, I. C., \& Charles, W. B. (1994). Utilization, socio-economic perspective and future prospects. In I. C. Onwueme, \& W. B. Charles (Eds.), Tropical root and tuber crops: production, perspectives and future prospects (chap. 20, pp. 156-158, FAO Plant Production and Protection Papers, No. 126). Rome: FAO.

Owusu-Darko, P. G., Paterson, A., \& Omenyo, E. L. (2014). Cocoyam (corms and cormels) an underexploited food and feed resource. Journal of Agricultural Chemistry and Environment, 03(01), 22-29. http://dx.doi.org/10.4236/jacen.2014.31004.

Pérez, E. E., Gutiérrez, M. E., De Delahaye, E. P., Tovar, J., \& Lares, M. (2007). Production and characterization of Xanthosoma sagittifolium and Colocasia esculenta flours. Journal of Food Science, 72(6), S367-S372. http://dx.doi.org/10.1111/j.1750-3841.2007.00420.x. PMid:17995692.

Perkin-Elmer (1994). Analytical methods for atomic absorption spectrometry. Norwalk: The Perkin-Elmer Corporation.

Rienzo, J. A., Casanoves, F., Balzarini, M. G., Gonzalez, L., Tablada, M., \& Robledo, C. W. (2014). InfoStat (versión 2014). Argentina: Universidad Nacional de Cordoba. Retrieved from http://www. infostat.com.ar/

Rodríguez, J., Rivadeneyra, J. M., Ramírez, E., Juárez, J. M., Herrera, E., Navarro, R. O., \& Hernández, B. (2011). Caracterización fisicoquímica, funcional y contenido fenólico de harina de malanga (Colocasia esculenta) cultivada en la región de Tuxtepec, Oaxaca, México. Ciencias Marinas, XV(43), 37-47.

Sadasivam, S., \& Manickam, A. (1996). Carbohydrates. In S. Sadasivam, \& A. Manickam (Eds.), Biochemical Methods (2nd ed., p. 1-21). New Delhi: New Age International.

Sefa-Dedeh, S., \& Agyir-Sackey, E. K. (2004). Chemical composition and the effect of processing on oxalate content of cocoyam Xanthosoma 
sagittifolium and Colocasia esculenta cormels. Food Chemistry, 85(4), 479-487. http://dx.doi.org/10.1016/S0308-8146(02)00244-3.

Simsek, S., Whitney, K., \& Ohm, J. (2013). Analysis of cereal starches by high-performance size exclusion chromatography. Food Analytical Methods, 6(1), 181-190. http://dx.doi.org/10.1007/s12161-012-9424-4.

Tan, I., \& Halley, P. J. (2014). "Structure-property" relationships of genetically modified starch. In P. Halley \& L. Avérous (Eds.), Starch polymers: from genetic engineering to green applications (1st ed., p. 31-69). Oxford: Elsevier. http://dx.doi.org/10.1016/B978-0-44453730-0.00020-8.

United States Department of Agriculture - USDA. (2012). Census of agriculture: Puerto Rico island and municipio data (vol. 1, Geographic Area Series Part 52). United States: USDA. Retrieved from https://www.agcensus.usda.gov/Publications/2012/Full_Report/ outfying_Areas/prv1.pdf

Vatanasuchart, N., Niyomwit, B., \& Wongkrajang, K. (2012). Resistant starch content, in vitro starch digestibility and physico-chemical properties of flour and starch from Thai bananas. Maejo International Journal of Science and Technology, 6(2), 259-271.

Yoo, S., \& Jane, J. (2002). Molecular weights and gyration radii of amylopectins determined by high-performance size-exclusion chromatography equipped with multi-angle laser-light scattering and refractive index detectors. Carbohydrate Polymers, 49(3), 307314. http://dx.doi.org/10.1016/S0144-8617(01)00339-3.

Zhu, F. (2016). Structure, properties, and applications of aroid starch. Food Hydrocolloids, 52, 378-392. http://dx.doi.org/10.1016/j. foodhyd.2015.06.023. 